\title{
WHY (MOST) HUMANS ARE MORE IMPORTANT \\ THAN OTHER ANIMALS: \\ REFLECTIONS ON THE \\ FOUNDATIONS OF ETHICS
}

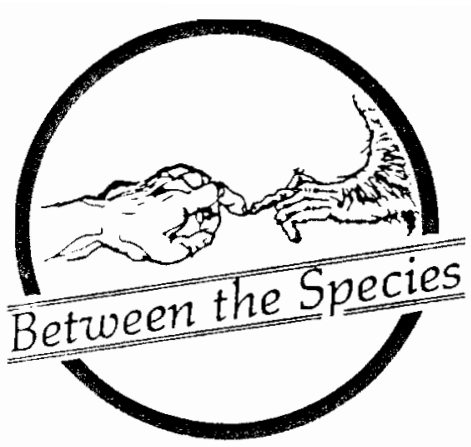

\section{CHARLIE BLATZ}

Univer:ity of Wyoming

I. The Setting of the Problem

Animals are used both as a source of energy for the production and transportation of agricultural products, and also as themselves a source of food and fiber. Many now question the justifiability at least of treating animals as themselves consumable products.

Specific practices of animal agriculture have cone under fire, as well as the entire phenomenon of raising and managing animals in order to eat them or to wear their skin, fur, or fibers. Those who have attacked such dealings with nonhumans have employed strategies designed to challenge one of two claims: either that nonhumans have no intrinsic ethical significance, deserve no serious attention on their own merits, or else that humans are more important than other animals.[1] Defenders of humans have met these attacks head-on.[2]

This discussion will be devoted mainly to these two issues: the intrinsic and relative importance of human and nonhuman animals. I shall present a detailed defense of a view rather like the position taken by Kant, arguing that ethical standing is to be reserved for ethical agents, excluding nonhumans and some humans. This leaves only a derivative importance for those who are not ethical agents. Later, I use these conclusions to make clear the complexity in assessments of particular animal agricultural practices and veganism.

\section{The Problem}

Let me begin with the issue of the inBEIWEEN THE SPECIES

\section{Editors' Note}

the contributions by Professors Sum isen and Charlie Blatz to the second Pacific Division meeting of the American Society for Value Inquiry, which was held in San Francisco in March, 1985.

trinsic importance of humans and other animals. What is the basis of ethical standing or of a being's deserving consideration in itself? First, let us get straight on the question. William $\mathrm{K}$. Frankena raises a related issue in an instructive way:

The point is that, in every ethics whatsoever, there are certain sorts of facts about certain sorts of things that are ultimate considerations in determining what is morally good or bad, right or wrong, and the question now is: what sorts of things are such that certain facts about them are the final determinants, directly or indirectly, of moral rightness or virtue?[3]

Frankena is concerned with moral standing, while I am interested, more generally, in ethical standing, whether moral, legal, prudential, or whatever. Still, with that difference in mind, the way Frankena raises the issue is very useful: what are the ultimate considerations in determining what is justifiable or not, and what beings manifest those? Every ethic begins somewhere, saying

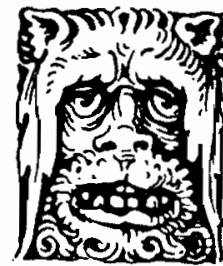

PHILOSOPHY 
that the objects of certain aims or certain pursuits thenselves are justifiable to realize or engage in and this is not due to their relation to some other justifiable aim or pursuit. These are the beginning points of justification in the ethic in question. At least, they are the beginning points, conflicts aside: the sources of what Ross considered prima facie duty and what consequentialists might call a, but not necessarily the, right or optimific act. [4] The characterization of these beginning points would fill out the antecedents of the most general norms of the ethic, those hypothetical claims to the effect that if an aim or pursuit is of a certain sort, then it is justifiable, conflicts aside. These norms, in turn, would enter into the justification of other norms of the ethic (by what Paul Taylor calls "validation") and into the justification of particular acts, either directly or through derived norms (by the process Taylor calls "verification").[5] These ultimate considerations, conflicts aside, I call "the seeds of justifiable conduct" in an ethic.

Different ethics identify different seeds, classical utilitarianism, for example, selecting pleasure and the absence of pain as the basis of what John Stuart Mill calls its "theory of life," while religiously oriented ethics, for example, select among various possible versions of enlightenment or beatitude.

Once we know what the seeds of an ethic are, we can identify conditions or beings who do (or might) manifest those seeds, and then these will have standing or be considerable within that ethic. That is, they will be conditions or beings whose presence, sustenance, and pursuits can be justified (conflicts aside) without reference to anything else other than their manifesting (or perhaps being able to manifest) the seeds of justifiable conduct.

Questions of the justifiability of animal agriculture begin with questions of what are the seeds of justifiable conduct and in what are they manifested. Are they found only in beings within the domain of humans, or does theix range extend beyond to nonhumans as well? To assess animal agriculture, we first need to select among the various possible views of seeds and, in the bargain, among the various possibilities for assigning ethical standing.
How might we make this selection? Some have thought that this question amounts to asking how might we find what the correct ethic counts as seeds of justifiable conduct and the possessors of ethical standing? [6] That view of the matter, however, rests upon a fundamental confusion.

The problem should be familiar to philosophers. In order to select the method that will deliver the correct view of seeds of justifiable conduct (or in order to know that a method will fail to do so), we would have to have some way to attest to the reliability of the methods we select from. This in turn requires that we already have some grasp on what really are seeds in a correct ethic. Grasping the seeds of justifiable conduct, however, amounts to knowing the (basic) norms, and so, the ethic we seek. Thus, to select a method to identify the correct ethic requires that we first have in hand the correct ethical theory. That, of course, is incoherent. Thus, it seens that nothing will satisfy getting at the correct ethic.

Picking between different conflicting views of seeds and who has standing is not to be taken as a matter of selecting the correct view of these matters.[7] It is not, then, a matter of discovery, of our learning what is really the case ethically and then suiting our beliefs about acceptable standards to the facts. What then is it?

The only thing to say seens to be that we decide what aims are seeds and what beings have standing. We simply must make up our mind without any pretense of meeting a test of truth or of satisfying an aim of accuracy. But what guide do we have for our decision? Is there any? Are these decisions just arbitrary, a matter of what feels right? Are they to be settled, then, by hurling ad hominems such as "species chauvinist" or "crazy environmentalist"? As it turns out, there is at least one perspective on the selection of seeds which is alternative to searching for the correct ethic and which does not just abandon the problem to caprice.

The suggestion comes from Rudolf Carnap's radical Kantian approach to questions of what exists. [8] Carnap recognizes that if we stand outside of all commitments to what kinds of things might exist, and so outside of all standards or tests of what does exist, we have moved outside all correct (or, as he 
put it, "theoretical") answers to questions of what there is. From such a vantage point, questions about what kinds of things there are should be viewed as external questions. These call for a decision not a discovery. And for Carnap, their decision is a "practical" one, based wholly on what answer will most effectively and efficiently serve the purposes of those asking what exists: purposes, e.g., of constructing a theory of the foundations of mathematics or of empirical science.

Applied to our problem, this suggests the following. We have just seen that trying to find the ethically correct picture of seeds and that of the assignment of standing is incoherent. The proper determination of these matters is external to any specific ethic. The answers will provide us with norms of what is justifiable, conflicts aside, and of who or what has ethical significance on its own merits. There is no correct answer to such puzzles, an answer internal to some view of what is justifiable and of who or what has intrinsic significance. We need a decision, not a discovery.

And following Carnap's radical Kantian lead, we would make the decision on the basis of what could serve well the purposes for which we have ethical codes. We would ask, how would seed aims and ethical standing be specified in a code most appropriate to the aims of anyone embracing any ethic. This, I shall call "the functionalist approach" to our problem.

Should we follow Carnap's functionalist lead in deciding upon an ethic to guide us in matters of animal agriculture? Yes. Otherwise, the ethic we select would be pointless, and so it would be unacceptable. Let me explain. To identify the point of an ethic, as I understand that here, is to single out what it is about, the code that allows it to play a role making some difference to our lives and those of others, to have some function for sone being. An ethic's point is whatever makes possible its having some impact upon our lives, an impact that is attributable to the ethic itself or to its operation.

Now, whether an ethic has some point or not is quite important to being acceptable. If a code is acceptable, as opposed to unacceptable, then its adoption is not arbitrary, not just something that would not matter at all. An ethic without point, however, is one whose adoption would be arbitrary. Without point, an ethic would make no impact upon anyone. There would be nothing attributable to any impact that would make any difference to anyone and so might be counted in its favor or against it. Adopting it then, or not doing so, for that matter, would be arbitrary, and so the ethic would not be acceptable as opposed to unacceptable. Thus, if an ethic is acceptable, then it has point.

This result puts limits on what an acceptable ethic might say about seeds and standing. The problem from this functionalist perspective is not how to find what norms correspond to some ethical reality but, rather, to consider what we would need to count as seeds of an ethic, any ethic, if it is to have any impact at all upon us or others. A minimally acceptable ethic will have those features, including seeds, which allow it to function in some way such that it makes some difference to our lives or those of others. What might be the seeds of justifiable conduct and who or what might have standing in such a functional ethic? That is the problem we need to address.

\section{III: The Answer to the Problem}

My main contentions in this section are two: first, some ethics do have point, and in fact, there is one characterization that fits any point that any ethic might have. Second, having this cormon feature does place restrictions upon what aims and pursuits are acceptably counted as seeds. As we shall see, these restrictions are quite general, but still extremely important here. As it turns out, they deny ethical standing to nonhuman animals, indeed, to any but ethical agents.

To make good these contentions, we need to begin with an account of the point of any ethic. Kant, in the Foundations of the Metaphysics of Morals, reminds us that ethics always have their impact through influencing choice and behavior by considerations appealing to reason and bearing on the justifiability of our options. [9] The first main point of my argument is this Kantian one: if there is any impact that is attributable to the operations of a code of ethics itself, then it is an impact that the code has by directing choice and behavior through the application of its norms to the options facing 
agents, through a directing influence upon the airns and pursuits of agents, an influence he code exerts by providing reasons pro and ontra the options open to the agent. Let me refer to that clain as "the functionalist's principle." According to this principle, then, the most general impact of ethics is to facilitate the choice and pursuit of options by providing reasons marking aims and pursuits open to us as justifiable or not.

This contention seems so fundamental to all of ethical theory that it is difficult to know just how to argue best for it. Ethics, as Frankena puts it, are action guides, and how else might they serve in this capacity but through providing reasons for or against the various options facing agents. It matters not how we see the operations of these reasons, for example, in a cognitive way, as did Kant, of as emotively persuasive, in the various ways that $C$. L. Stevenson sketched for us.[10] The conclusion is the same: ethics include, no matter what else, evaluations more or less general in scope, [11.] evaluations that provide reasons pro or contra. And, if an ethic so understood is to have an impact, it must be the impact of the direction of reason upon an agent's aims and pursuits. The functionalist's principle records this point and, as such, seems uncontroversial.

Perhaps, beyond relying on just that much, however, it would be wise to note an intolerable consequence of rejecting the functionalist's principle. Ethics are thought to have no point for very young infants and for nonhuman animals. This is simply because their aims and pursuits are not open to the influence of justifying reasons. Even Tom Regan, that most thorough champion of animal rights, grants this (as do Peter Singer and Bernard Rollin, for examole). He notes that nonhumans are not etrical agents and that the impact ethics would lave on nonhumans must come through the influence of its justifying reasons upon ethical agents. [12] But that is just to say that the point of ethics cepends on their influencing choice and behavior through such recsons. It is just to assert the functionalist's principle. A rejection of that principle would leave open the question of whether ethics have point for young children and nonhuman animals. Since no serious party to the debate over animal agriculture seens to take that question as open, a rejection of that principle would be unacceptable.

To say that the point of ethics is lost on youngsters and nonhuman animals, or that ethics are without point for them, is not to say that how they are treated does not matter ethically.[13] The next question, then, is what are we to conclude from the functionalist's principle? Might a being have ethical standing and ethics still be without point for it? or is it that any being on which or whom ethics is lost lacks ethical standing and is important only because its welfare is tied up with the aims and pursuits of those for whom ethics do have point?

Ethics that have point satisfy the functionalist's principle, their impact coning through an influence on aims and pursuits due to the justifying reasons of the ethics' norms. Clearly then, if an ethic is to influence choice and behavior through reasons, the influence will be exclusively on those whose choices and behavior can be directed by such reasons, namely, ethical agents. It will be the aims of those agents that are singled out as justifiable or not, the aims of those agents which the code marks as acceptable or not. Otherwise, the normative guidance would fall on deaf ears.

Thus, aims identified as seeds by the ethic's basic norms will belong to ethical agents. They might be directed toward the well-being of non-ethical agents (as we shall make much of later), but the direction of an ain is irrelevant to whether there is any point to marking it justifiable or not. Whether there is any such point depends on whether those aims belong to ethical agents. The fact that seeds in a code are the aims of ethical agents is what allows that code point. It is this that is necessary to its not being arbitrary. It is this that assures its minimal acceptability. So, any ethic acceptable in so far as it has point will locate its seeds among the aims of ethical agents (those open to being guided by the justifying reasons it provides). [14] Let me call that the "rationalist's principle."

We have noted that the ethical agents of codes with point are restricted to the group of humans (though are not necessarily coextensive with that group). Thus, the implication of the rationalist's principle is that the seeds of any ethic with point will be aims and pursuits of humans, as opposed to 
nonhumans.[15] Since ethical standing belongs to whatever manifests the seeds of justifiable conduct, it is some humans and not other animals that exclusively enjoy such standing. Nonhuman animals, then, lack ethical significance on their own, at least in any ethic that might have any impact upon our lives or those of others. What significance nonhuman interests and well-being have in such an ethic is due to their being objects of the aims and pursuits of ethical agents. If these aims are seeds of justifiable conduct in an ethic, then, conflicts aside, they are justifiable to pursue without regard to other considerations. As objects of such aims, nonhuman animal welfare, freedom, and so one have a kind of fundamental importance. still, this is an importance nonhumans have because of the standing of those ethical agents who are their champions. It is derivative upon the import of these human, as opposed to nonhuman, champions. This result I shall. refer to as "the humanistic restriction of ethical standing."

\section{IV: Amplification of the Answer}

Those with ethical standing are, then, among the group of humans. What, however, about the significance of nonhumans as conpetitors in conflict with humans? What of the relative import of humans and nonhumans?

The interests of nonhumans might end up more important than competing human interests in certain codes. This could happen in any ethic that allows nonhumanly directed aims as seeds and has a norm(s) of conflict resolution that allows such aims to win out over the competition. Do acceptable ethics operate this way?

The answer is "yes," but to make good the point, we must say more about when ethical codes are acceptable. All we have said thus far is that a code is acceptable only if it has some point.

So far, so good, for surely an ethic that had nonhumanly interested aims as seeds and whose norm(s) of conflict resolution allowed such aims to win out over the competition would be an ethic with point. In particular, it would provide guidance on how to settle conflicts between such aims and ones that are humanly interested, guidance which could give highest marks to the nonhumanly directed aims in some circumstances.
While we are at it, however, we can say even more on behalf of this minimal animal lover's ethic. Notice that there is a second aspect to an ethic's being non-arbitrary. Adopting an ethic without point would be arbitrary, because there is nothing to say for or against adopting it as opposed to no ethic at all. Another aspect of arbitrariness can enter in when we choose between two or more ethics, all of which have point but which offer inconsistent guidance on the same matter. In this second way, adopting an ethic would be arbitrary if it restricted, for no reason, the seeds of justifiable conduct and the aims that can win conflicts. Adopting such restrictions would be biased and so question begging against those aims not counted as seeds or allowed to win a conflict. Only our minimal animal lover's ethic is not arbitrary in this second way.

Clearly, we would beg the question unless we allowed nonhumanly directed aims the status of seeds of justifiable conduct. After all, what could serve as a reason for ruling them out? Whatever could do the job would have to imply that excluding them is justified for some reason. As we saw above, however, no reasons can be given for saying that certain aims are or are not seeds. Such a claim is external to all ethics and itself constitutive of justifying reasons. Thus, denying seed status to nonhumanly directed aims would be without reason and so question begging. The animal interest advocate woulci reject it, and insisting upon it would be arbitrary, biasing the discussion in an unacceptable way.

The same can be said against an ethic whose basic norm(s) of conflict resolution would not allow nonhumanly interested aims to win out in conflicts with other aims. This norm(s) of conflict resolution is the fundamental ethical consideration that tells us which of two or more incompatible courses of action is justifiable. Considering its role as an ultimate ethical consideration, there is nothing that would provide a justifying reason for such a norm, nothing whose assertion or support does not already assume the acceptability of what that norm claims. Thus, if a basic standard of conflict resolution excludes certain aims from winning--for example, nonhumanly interested aims--it would be arbitrary or question begging, and so, unacceptable.

The only conflict resolution principle 
which would avoid this problern gives every conflicting aim an equal chance at winning out over its competitors. It accords as much importance to any one aim as it does to every other competing aim, as much to nonhumanly directed aims as to exclusively humanly directed aims. Now, if a principle is to ac-

cord equal importance to every competing aim and yet resolve conflicts, it will proceed by urging whatever course of action will maximally allow for the pursuit of all aims affected in the conflict situation.[16] If, for example, animals are needed for protein to such an extent that raising them for slaughter and consumption would be what would maxinally facilitate the aims and pursuits of all those affected, animal lovers and not, then that would be the non-question begging way to settle the dispute. If not, then it would not be.

What, then, about an ethic counting nonhumanly interested aims as seeds of justifiable conduct and allowing them to win out in conflicts with other aims? only this minimal animal lover's ethic will avoid arbitrariness on the two counts we have isolated. It will have point by providing guidance on issues where we need it, and only the guidance it provides will be non-question begging.

More than avoiding arbitrariness enters into the acceptability of an ethic. But we shall stop here, for now. This much should create a presumption in favor of this minimal animal lover's ethic and against alternatives to it. It is now time to apply this ethic to what we should say about conflicts over raising animals for food and fiber.

\section{V: Applications of the Answer}

This question turns out to be an enormously complex and partially factual inquiry. It amounts to this: just what treatment of nonhuman animals in agriculture will be such as to maximally serve the aims and pursuits of all those ethical agents affected by the conflict's outcome. Confronted by such a problem, it would be silly to give the appearance of providing a final answer. I shall say, instead, only a bit, trying to make clear the complexity of some of the subissues.

Consider, first, some of the charges that have been levelled against the proce- dures used in animal agriculture. Perhaps the most notorious case is that of veal production. Veal calves are generally kept in puarters that virtually eliminate all but some head movement and the freedom to lie down. Social conduct is essentially precluded. Their diet is basically liquid. Their environment is often dark. Their life is invariably short. The object of all this is to produce quickly and economically a tender meat product for a limited but continuing market. The animal is treated just as a tissue factory whose concern to the producer. amounts to how well it performs in putting on flesh in a short period of time.

All of this sounds diabolical, as though certain famers have set out to contrive management practices that will thwart every natural striving of the animal incorpatible with a higher profit. However, a closer look indicates that this view of the matter is, at best, only mostly correct. In the first place, most producers of veal would not even engage in the practice, regardless of procedures used, if the choice were up to them. Veal calves are mostly the male offspring of dairy cows, a progeny which is a problem to the dairy farmer. What is the farmer to do with such an animal?

Asking the farmer to raise and keep the animals would be imposing a serious financial burden on them. Without further regulations, this is a burden they can be expected to try to externalize. Since the dairy industry is already heavily subsidized, however, it is hard to imagine what most farmers would be able to do besides just cheat and destroy immediately those animals that would have been raised for veal.

Regulating the market so that only certifiable male dairy cow off-spring could be sold for slaughter as calves and requiring that they be sold by the animal, rather than per pound, for an amount equal to expenses might well serve to remove all the incentive there is presently for the use of intensive techniques. The practices described above are devoted to getting as much out of the animal as possible by selling it per pound in the shortest period (usually 2 to 3 months). If there were no profit in such techniques, they would pass, assuming the critics are correct about the veal producers' basic motivation. Any scheme like this, however, would also have to require that the farmers keep 
the animals healthy so that selling calves by the animal would not lead to neglect. Regulations that would do all this would no doubt be expensive to administer and intrusive. Who would pick up the costs or pat up with the intrusions?

Perhaps, then, we should attempt to reeducate tastes, thereby undermining the market for veal? This, if effective, eventually would eliminate the unwanted intensive production, all right. However, the famer will still have the animals to contend with. Thus, in all likelihood, we would have traded those objectionable practices for the immediate disposal of animals that would have been raised for the veal market.

What should we do, then, in the face of intensive veal production practices? I, like the so-called "animal lovers," find these practices objectionable, because, like them, some of my aims are directed toward not harming most other sentient creatures when this can be avoided at an ethically justifiable cost. Intensive veal production techniques seem to involve putting the animals in circumstances they would avoid if they could, and on this basis, the practices seem harmful to the animals considered as sentient creatures with a life of their own. The loss of avoiding this harm would be monetary and gustatory, losses that are surely repairable and bearable, if we choose to repair and bear them. The protein of animals raised in these ways is not needed to maximally facilitate the aims and pursuits of all those in active conflict over the practices, let alone all those affected by the outcome of the conflict. One wonders what justification could be given for such practices if we appeal to an ethic that has point and is not question begging at the foundations? But, then, we just do not yet have all the facts, do we?

Although there are differences in the animals, the management practices, and the market size, some of the same sorts of points can be made about the treatment of brood sows. Unlike the veal calf, the brood sow is actively sought in order to function as a reproductive factory, which involves considerable restraint in movement. Intensive hog raising practices, including sow restraint, mark a change over previous, more free-ranging management techniques and were introduced in order to increase productivity and profit. critics have urged that, at the least, these

BETWEEN THE SPECIES intensive practices are unjustifiable and ought to be eliminated. Some producers and production experts have defended them, often on a standard of animal welfare measuring only animal yield for profit.

Clearly, however, we lack the facts to decide the issue using a defensible ethic such as the one outlined above. For example, what would be the impact on the industry structure if we were to remove the profit incentive supposedly fueling the engine of such practices? would specialized producers be hurt the most and driven to take their capital elsewhere? Or would a larger sector of the farming community be hurt, impairing, in the end, a source of food going far beyond pork and important to all of us? Perhaps we could get along just fine in the end with no more intensive hog production, letting those who have the taste pay more? Do we know?

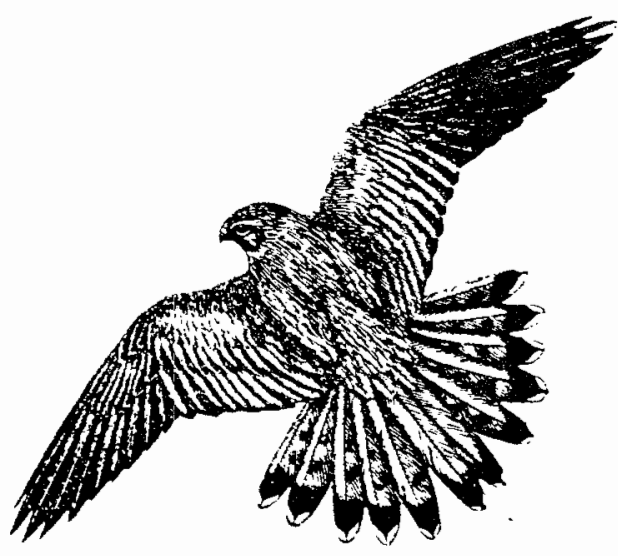

Jim Herter, Animals: 1419 Copyright-Free IIIstrations

The question whether to make consumers pay for less intensive production techniques looms large also when we turn to the wellknown conditions of intensive egg and poultry production. In the face of the decline of the family farm, as well as the urban- and suburbanization of the populations of Westerm industrialized countries, the intensification of egg and poultry production has served to provide a stable and relatively inexpensive source of complete protein. What would be the cost of replacing those intensive management techniques if we measured that price in terns of impairment of the aims and pursuits of the ethical agents touched by the conflict? Again, I think that we do not have a good idea of what to say.

That same question complicates the as- 
sessment of intensive production techniques in the case of beef. On the one hand, it Nould be most surprising if an acceptable thic could justify the practice of graininishing cattle in intensive feed-lot situaions. As Lappe points out, the grain could .e used elsewhere, [17] or else the land used to produce it could be turned to other products that could be used elsewhere. The food produced without this grain would be every bit as good a source of protein and to some, every bit as palatable as that produced with it. Further, note that the beef produced non-intensively on open range in many areas of the United States and other countries, such as Australia, makes productive for the benefit of ethical agents land that would otherwise not be useful. (The same is true for what is even a better use of such arid range, namely, sheep production for wool, lamb, and mutton.) Here, then, it seems that non-intensive techniques avoid indefensible waste while at the same time being productive for the overall benefit of ethical agents.

On the other hand, however, if a world source of complete proteins is the main issue, then intensive beef production, where economical and conducted without the waste of grain finishing, is likely to turn out to be defensible. And, how could an assessment of animal agriculture ignore the fact that in much of the world, human malnutrition is due to a lack of available whole or complete proteins?

Intensive beef production also might seem desirable in the face of social and environmental consequences of nonintensive beef production in areas of cheap lands and polarization of economic groups, areas such as are found in Central (and perhaps South) America. In those places, intensification of beef-raising might be able to accompany land reform that would leave the peasant agriculturalists better off economically, and in some cases could provide the opportunity to reduce environmental depredation. Again, however, the point to conclude with is that we just do not know about all of this.

The full weight of our ignorance and the complexity of the issues are made clear when we move from the criticism of animal food and fiber production techniques to the urging of veganism. A serious review of any move to veganism must assess the impact on the price and availability of vegetable protein sour- ces, the balance of diets with respect to the amount of usable protein in them, the channels of public information that would be needed in order to convert people's diets, the livelihood of those now making a living from the production of animal food and fiber, and the international relations centered on the production and distribution of animal food and fiber.

With a consortium of experts, no doubt we could carry out these assessments. But surely, we are not yet in a position to apply an acceptable ethical theory to the question of veganism.

\section{VI: Conclusion}

Agriculturalists and, more importantly, the legislators, regulators, economists, and economic elite who control the plans of agriculturalists need guidance on what are ethically defensible practices (if there are any) of animal food and fiber production. Philosophers can inform this guidance at its ethical base and by clarifying the epistemic and conceptual aspects of the basis. But we cannot do it all. As I have tried to illustrate, these questions lead us into enonmously complex factual matters. At least, this is so if our duties to animals are indirect.

My arguments show that these duties are indirect. To deny this is to advocate an ethic without point or one question begging in its foundations. Let us not be so foolish or biased as to do either. And, let us not act as though operating alone, philosophers can settle questions requiring complex enpirical inputs. In either event, we would be taking serious matters less than serious$l_{y \cdot[18]}$

\section{Notes}

1. See, for example, Peter Singer, "All Animals Are Equal," The New York Review of Books 22 (1975), reprinted in James E. White, Contemporary Moral Problems (Saint Paul: West Publishing Co., 1985(, pp. 266-78).

2. See, for example, Leslie Pickering Francis and Richard Norman, "Some Animals Are More Equal than Others," Philosophy 53 (1978), p. 527.

3. William K. Frankena, "Ethics and the Environment," in K. E. Goodpaster and K. M. 
Sayre, eds., Ethics and Problems of the 21st Century (Notre Dane: University of Notre Dame Press, 1979), p. 5.

4. See, for example, William David Ross, The Right and the Good (Oxford: The Clarendon Press, 1930) and William K. Frankena, Ethics, second edition (Englewood cliffs: Prentice-Hall, 1973).

5. Paul w. Taylor, Normative Discourse (Englewood Cliffs: Prentice-Hall, 1961), et passim, but especially Chapter 9 .

6. See, for example, Annette C. Baier, "Knowing our Place in the Animal World," in Harlan B. Miller and William H. Williams, eds., Ethics and Animals (Clinton: Humana Press, 1983), pp. 62 and 67.

7. The same result can be reached as an epistenic point. The question would then be how are we to show basic ethical claims to be incorrect, what evidence would we bring forward to show that? Since basic ethical claims are what show whether ethical claims are correct, nothing could count as evidence that they themselves are correct. Thus, there would be no such operation as providing evidence for the correctness of basic ethical claims. Striving for such evidence would be confused.

8. Rudolf Carnap, "Empiricism, Sernantics and Ontology," Revue Internationale de Philosophie II (1950), reprinted in Leonard Linsky, Semantics and the Philosophy of Language (Urbana: The University of Illinois Press, 1952), pp. 207-28. See especially pp. 31-2 (219-20). Also, see Immanuel Kant, Critique of Pure Reason, trans. by Norman Kemp Smith (London: Macmillan \& Co., 1963). Further, see the work of $W$. V. O. Quine and Richard Rorty.

9. Irmanuel Kant, Foundations of the Metaphysics of Morals, trans. by Lewis White Beck (Indianapolis: The Bobbs-Merrill Co., 1959), p. 12.

10. Charles L. Stevenson, Ethics and Lanquage (New Haven: Yale University Press, 1944), and Facts and Values (New Haven: Yale University Press, 1963).

11. I say "more or less" to include an extreme act intuitionist like E. F. Carritt, The Theory of Morals (Oxford: The Clarendon
Press, 1928).

12. See Tom Regan, The Case for Animal Rights (Berkeley: University of California Press, 1983), Chapter 5, and the Preface, respectively.

13. The question of nonhuman animal significance is addressed below, after I argue that only ethical agents have standing. The matter of the ethical significance of children is a complex one. Still, something inust be said here. For those old enough to be held accountable for their actions while on a shorter or longer tether, things are relatively straightforward. our holding them accountable presupposes that we regard then as ethical agents, ones whose lack of experience, conscientiousness, constancy, resoluteness, and clarity of purpose are such that we consider a heavier or lighter dose of paternalism to be the way to make most of their aims and pursuits ours and to make the most of their aims and pursuits which might conflict with those. For children not old enough to be held accountable and so not subject to the evaluations and influences of ethics, in particular, for very young infants whom we never scold or deal with through a firm "No!," the matter of their ethical significance is somewhat less direct. It is an importance they have because their welfare is an object of interest among ethical agents. It is (temporarily) derivative, I believe, as I argue the significance of nonhuman animals is (chronically). This is not to say that all those we treat as ethical agents, young children and the socially or intellectually retarded especially, are as open to the influence of justifying reasons as are other agents. Sometimes, our holding them to account is to no avail. But that changes nothing about their status. They are still being treated as ethical agents and, as such, have standing for reasons I shall argue in a moment. One other consideration comes into play with respect to children: if we accept some (logical) principle of universalizability, then we will receive in the bargain justified urgings to be conscientious by not limiting the occasions upon which our codes' basic norms can be put into practice. By not nurturing most of our children as ethical agents, we would fail to be conscientious in this way. The same thing is not true, of course, with respect to our treatment of nonhuman animals.

continued page 24 